http://journal.uinsgd.ac.id/index.php/biodjati

\title{
THE SELECTION OF ORNAMENTAL PLANT FOR LANDSCAPE DESIGN OF POLLINATION GARDEN AT BOGOR BOTANIC GARDENS
}

\author{
Peniwidiyanti $^{1 *}$, Irvan F. Wanda ${ }^{2}$, Dipta S. Rinandio ${ }^{3}$, Prima W. K. Hutabarat ${ }^{4}$, \\ Muhammad R. Hariri ${ }^{5}$, Dwi Setyanti ${ }^{6}$, Saripudin ${ }^{7}$
}

Received : January 24, 2020

Accepted : September 22, 2020

DOI: 10.15575/biodjati.v5i2.7480

1,2,3,4,5,6,7 Research Center for Plant Conservation and Botanic Gardens (Bogor Botanic Gardens), Indonesian Institute of Sciences. Jl. Ir. H. Juanda No. 13 Bogor 16122, West Java, Indonesia.

e-mail:

*1niwidiyan@gmail.com

${ }^{2}$ ivan.wandassi@gmail.com

3.sumeru.dipta@gmail.com

4hutabaratpwk@gmail.com

${ }^{5}$ muhammadrifqihariri@gmail.com

6wissetyanti@apps.ipb.ac.id

7uben.keren@gmail.com

*Corresponding author

\begin{abstract}
Bogor Botanic Gardens is one of the outstanding green areas in Bogor City. Thousands of plant species are growing and providing suitable habitats and feed for various pollinators, such as butterflies, bees, and wasps. A well-designed pollination garden will benefit the pollinators and also create an educational facility for the community. This study aimed to select and characterize species of flowering plants that effectively attract pollinators, particularly Lepidoptera and Hymenoptera, in the pollination garden candidate area. The observation had been carried out on 12 ornamental plant species: Pennisetum purpureum, Cosmos sp., Pachystachys lutea, Cuphea hyssopifolia, Orthosiphon aristatus, Lantana camara, Citrus aurantifolia, Buddleja davidii, Ixora javanica, Nerium oleander, Hibiscus rosa-sinensis, and Aglaia odorata. The method for observing pollinators was a standard walking method. Pollinator photos, its number, its visit time, and the plants it visited were recorded. A total of 23 species of Lepidoptera (20 species from 4 families and 3 species were unidentified) and 9 species of Hymenoptera (4 families) were found in the area with the best observation time at 08.30-09.30 (GMT+7). The most visited plants by pollinators were Cuphea hyssopifolia, Lantana camara and Orthosiphon aristatus. Lepidoptera and Hymenoptera preferred blue-purple and bright-orange-yellow flowers. In addition, the flower characters that might influence pollinator visits are also described. The result would be an essential recommendation for plant selection, landscape design, and construction of the pollination garden in Bogor Botanic Gardens.
\end{abstract}

Keywords: botanic gardens, pollination garden, flower characters, landscape design, pollinator

\section{Citation}

Peniwidiyanti, Wanda, I. F., Rinandio, D. S., Hutabarat, P. W. K., Hariri, M. R., Setyanti, D \& Saripudin. (2020). The Selection of Ornamental Plant for Landscape Design of Pollination Garden at Bogor Botanic Gardens. Jurnal Biodjati, 5(2), 223-235.

\section{INTRODUCTION}

Pollinators are common in the tropics (Ollerton, 2017) and capable of pollinating up to $87 \%$ of flowering plants. Therefore they can show the change in land use (Winfree et al., 2011). In an ex-situ conservation area such as botanic gardens, the plant species that are planted may not commonly found naturally in the area. It may influence and change the pre- 


\section{JURNAL BIDDJATI}

http://journal.uinsgd.ac.id/index.php/biodjati

ference of pollinators within the area. Many local and exotic pollinators in botanic gardens have been studied, mainly their behaviour and preference in pollinating local and introduced plants (Webber et al., 2012). Today, the study of pollinators is used to study the evolution of Invasive Alien Species (IAS) to explain the ecological functions and the evolution of pollinators in IAS ecosystems recipient (Vanbergen et al., 2018). Therefore pollinators can play a role as an indicator of plant diversity in an ecosystem, particularly in tropics that have many species of plants.

Bogor Botanic Gardens (Kebun Raya Bogor) is home to thousands of species that provided food and habitat for many pollinators such as birds, bats, squirrels, butterflies, and bees. On the other hand, the existence of pollinators in the area has ecologically benefit for flowering species to regenerate (Kato et al., 2008). Beyond that, this mutualism symbiosis has shown a crucial ecological role in maintaining plant diversity (Ollerton, 2017). Several studies on pollination of living collection by pollinators have been carried out in the garden, namely observing flowering and insect pollination of Areca vestiaria (Utami \& Kahono, 1989), fruit-eating and nectar-eating bat (Soegiharto \& Kartono, 2009), reproductive biology and insect visitors to Cassine koordersii (Ardhianto et al., 2009), insect pollination of Rafflesia patma flower (Kahono \& Mursidawati, 2010), and guidance on butterfly introduction practices at Bogor Botanical Garden (Peggie \& Amir, 2006).

The botanic garden is one of green space that plays essential roles, both ecologically and socially. The importance ofa botanic garden function in conservation, research, education, tourism and ecosystem services are conveyed in a presidential policy 93/2011 (2011) that regulates botanic garden status and development in Indonesia. The existence of a botanic garden in a city does not only play a role in providing a green space but also in supporting ecosystem balance in a city that is more complex and challenging.

Urban communities demand a green space for social activities such as gathering, casual sports, hobbies and educational activities, provided by a botanic garden. Educational activities in a botanic garden can be an appropriate approach to deliver the mission of the botanic garden in increasing public awareness of botanical and environmental issues. The importance of the pollination issue can be delivered through developing a thematic garden, namely "pollination garden". The pollination garden should be able to provide public experience seeing the natural pollination process in nature, an example and recommendation of gardening practices and to stimulate communities in supporting and helping pollinator fitness. Well-planning landscape design of a pollination garden is not only appropriate for the local area but also has a scientific base and references, which will improve the ability to attract pollinators.

This study aims to evaluate and select the efficacy of some local ornamental plants which have the potential to attract Lepidoptera (butterflies), and Hymenoptera (bees and wasps) in the candidate area of pollination garden in Bogor Botanic Gardens (later called as pollination garden), along with characterizing the flower and the pollinators. The result will be part of recommendations that benefit the process of plant selection, landscape design and construction of pollination garden in Bogor Botanic Gardens.

\section{MATERIALS AND METHODS}

\section{Study Area and Data Collection}

This research is an experimental study conducted in August-December 2018 at 


\section{JURNAL BIDDJATI}

http://journal.uinsgd.ac.id/index.php/biodjati

Bogor Botanic Gardens, Bogor City, West Java, Indonesia. Twelve local ornamental plants were tested in three plots, $5 \mathrm{~m}^{2}$ each, located in the candidate area of pollination garden (Figure 1). They were Pennisetum purpureum, Cosmos sp., Pachystachys lutea, Cuphea hyssopifolia, Orthosiphon aristatus, Lantana camara, Citrus aurantifolia, Buddleja davidii, Ixora javanica, Nerium oleander, Hibiscus rosa-sinensis and Aglaia odorata. Those species were chosen and justified based on the family of species, the role of species as a host plant and food plant (Subahar \& Yuliana, 2010) and personal communication.

The area of the pollination garden covered about $8776.94 \mathrm{~m}^{2}$ and is located in the southeast of Bogor Botanic Garden (Figure 1). It is laid on the section XIX.K, XIX.N and XIX.M. The temperature was around 22$32^{\circ} \mathrm{C}, 78.30 \%$ in relative humidity, 7 hours of photoperiodicity, and the average wind speed was $2 \mathrm{~m} / \mathrm{s}$ (Indonesian Meteorology, Climatology, and Geophysics Center, 2018). The surrounding area is heavily shaded by canopy trees, while most of the central area in the day time was fully exposed by the sun, with some part was shaded by small trees. A big pond in the middle of the area that acted as a water source and insect attractor.

The observation was used the standard walking method (Pollard \& Yates, 1993; Tati-Subahar et al., 2007) in each plot and started at $08.00-11.00(\mathrm{GMT}+7)$ as the most active period for butterfly (Kunte, 1997). Each butterfly and bee species have found from the plot were recorded and taken photographs, for identification of butterflies "Practical Guide to the Butterfly on the Bogor Botanic Garden" (Peggie \& Amir, 2006) was used along with expert discussion and consultation. In addition, we consulted "Plant Identification Terminology: An Illustrated Glossary" (Harris \& Harris, 2004) for identification of the floral character of plant species we used. The factors which were observed included flower characters, butterflies and bee species, and frequency of pollinator visit.

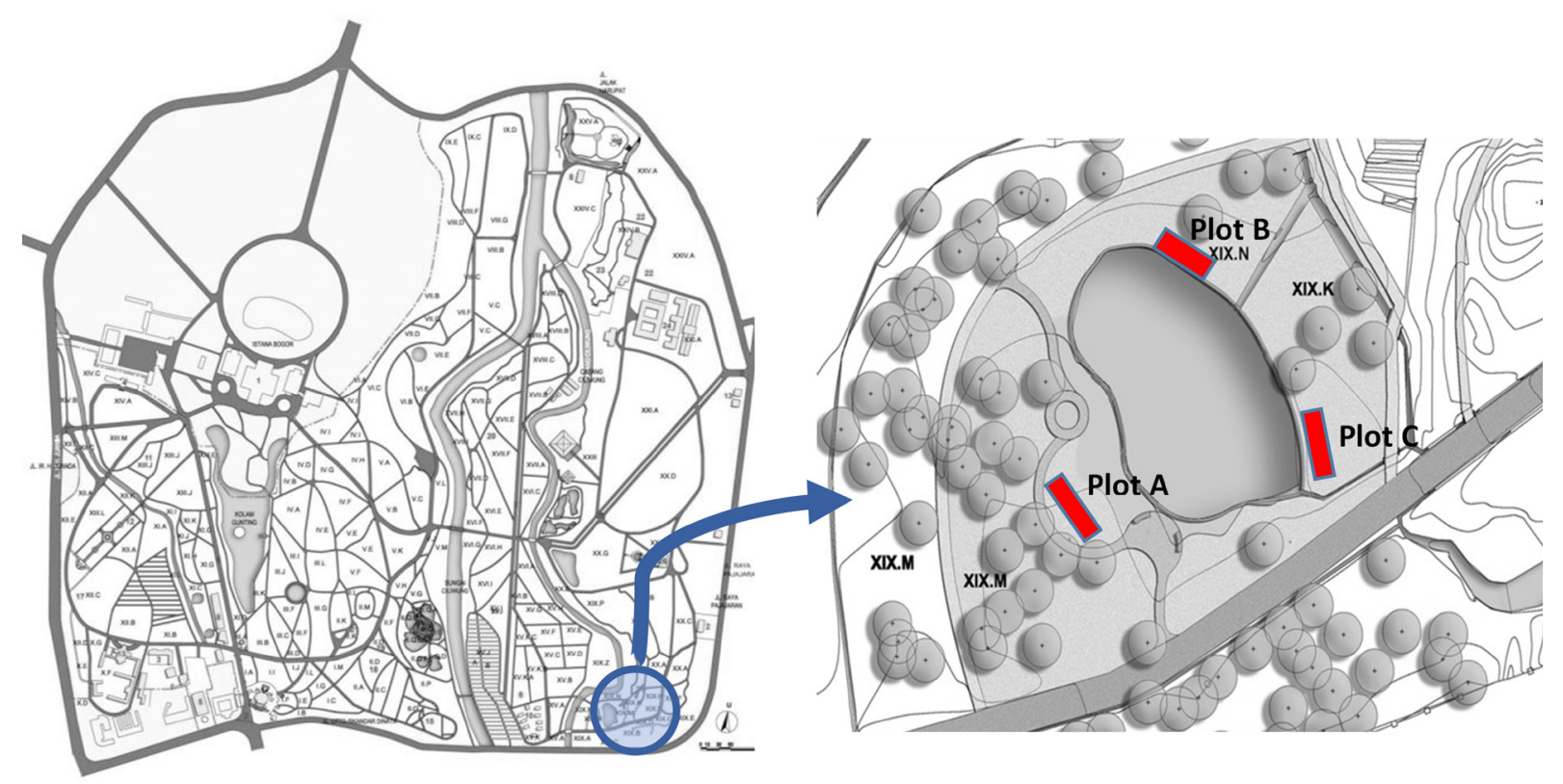

Figure 1. Ornamental plant observation plots for attracting pollinators at the candidate location Pollination Gardens, located on the Vak. XIX.K, XIX.N, and XIX.M in Bogor Botanic Garden. 


\section{JURNAL BIDDJATI}

http://journal.uinsgd.ac.id/index.php/biodjati

\section{Data Analysis}

Lepidoptera is the largest plant-feeding order of insects that has an ecological function as pollinators and prey. Lepidoptera has more than 43 superfamilies, one of which is Papilionoidea as the largest clade consisting of butterfly relatives (Mitter et al., 2017). Another largest insect order is Hymenoptera, which is consisting of sawflies, wasps, ants, and bees (Peters et al., 2017). The presence of Lepidoptera and Hymenoptera could be analyzed and figured out by comparing the number of species richness, species diversity, and species evenness. Data analysis was carried out to determine the diversity of pollinators in the pollination garden using the Margalef index (R), Shannon-Wiener diversity index $\left(\mathrm{H}^{\prime}\right)$, and Evenness index (E). Margalef Index is a richness index where $\mathrm{S}$ is the number of species observed, and $\mathrm{n}$ is the total number of individuals of species in plots, and $\ln$ is a natural $\log$, so the richness index formula is $\mathrm{R}=(\mathrm{S}-1) / \mathrm{ln} \mathrm{n}$. Richness index explaining that $3,5<\mathrm{R}<5,0$ shows moderate species richness and $\mathrm{R}>5,0$ shows high species richness.

Furthermore, Shannon-Wienner diversity index was used to determine diversity, which can be calculated by the proportion of the first species in the total sample (Pi) multiplied by the natural $\log (\ln )$ of the proportion of the $i$ species in the total plot. The formula of a diversity index is $\mathrm{H}^{\prime}=\mathrm{Pi} \times \ln \mathrm{Pi}$. The diversity index divides into three criteria, namely $\mathrm{H}^{\prime}<2$ shows low category, $2<\mathrm{H}^{\prime}<3$ shows medium category, and $\mathrm{H}^{\prime}>3$ shows high category. The evenness index aims to determine the level of species distribution. The formula of an evenness index is $E=H^{\prime} / \ln S$.
Magurran (1988) has stated that the value of Evenness index is close to the values of 1 that mean there are no dominant species in the area. There are parameters index still relevant to Hymenoptera and Lepidoptera biodiversity analysis (Kwatrina et al., 2018; Budiadi et al., 2020). Principal Component Analysis (PCA) using XLStat 2014 was used to analyze the relationship between the pollinator interests in the plant species.

\section{RESULTS AND DISCUSSION}

\section{Floral Characters}

Twelve species of flowering ornamental plants from different families show diverse flower characters (Table 1). Five species of flowering plants throughout the observation produced many flowers multiple times, namely Cosmos sp., Pachystachys lutea, Cuphea hyssopifolia, Orthosiphon aristatus, and Lantana camara. Meanwhile, the other species have infrequent and short flowering period. They are perennial plants with bright colors, some do not have a scent while others have a strong scent.

\section{Diversity and Abundance of Pollinators}

There were 23 species of Lepidoptera (20 species from 4 families and 3 species were unidentified), and 9 species of Hymenoptera (4 families) recorded during this study. The relative abundance of insect pollination also varied (Table 2). In Lepidoptera, species with a high abundance were Junonia atlites and Eurema sp., while in Hymenoptera, the highest abundance was Amegilla sp. 
Jurnal Biodjati 5(2):223-235, November 2020

\section{JURNAL BI@DJATI}

http://journal.uinsgd.ac.id/index.php/biodjati

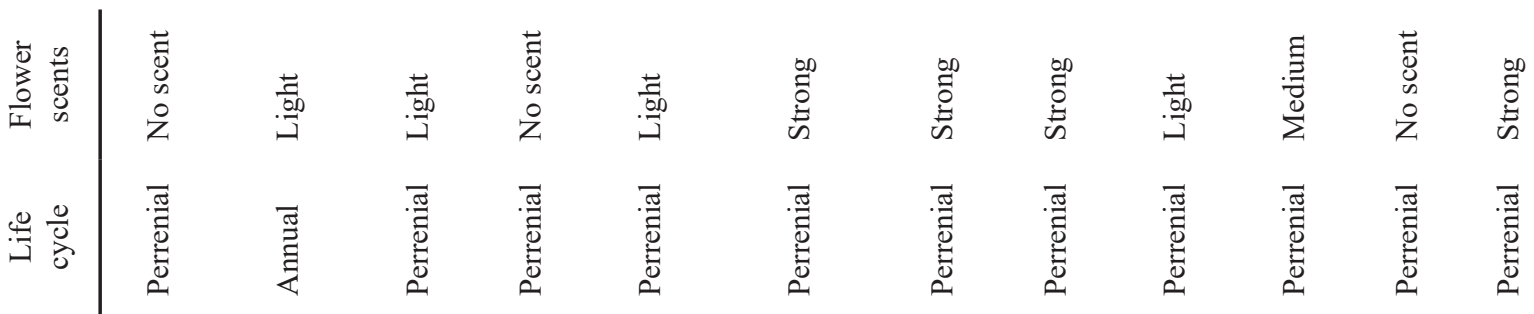

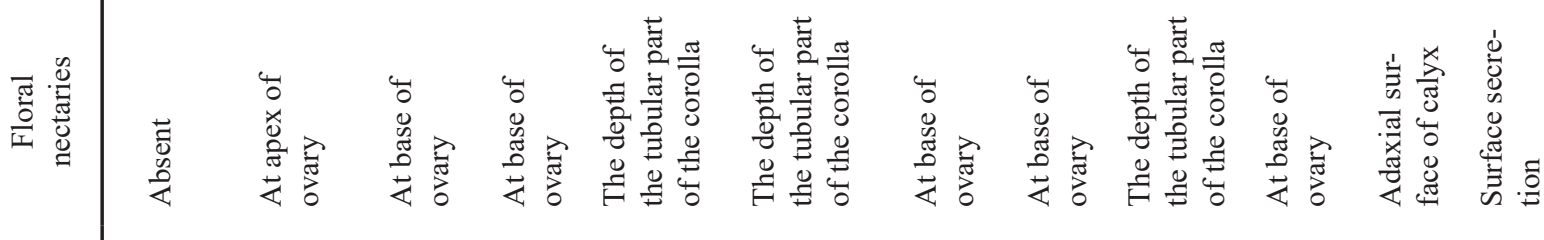

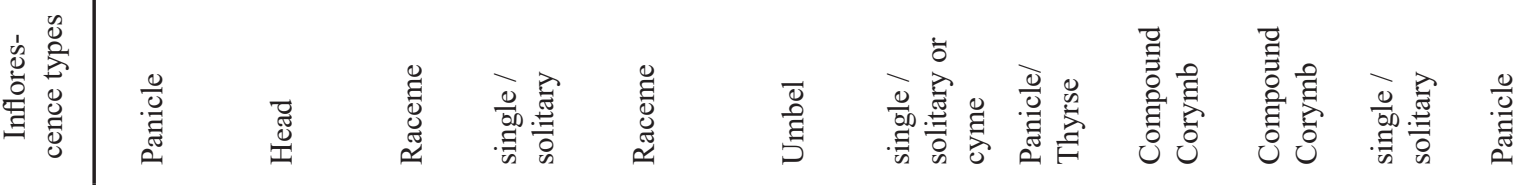

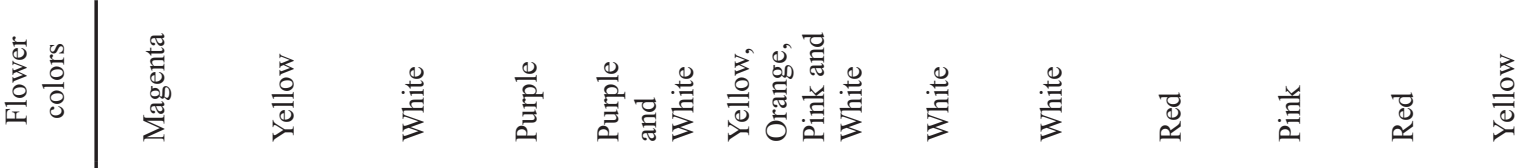

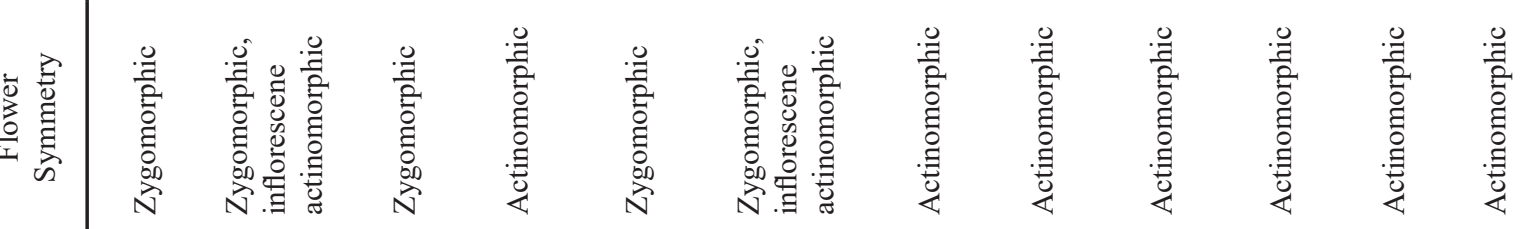

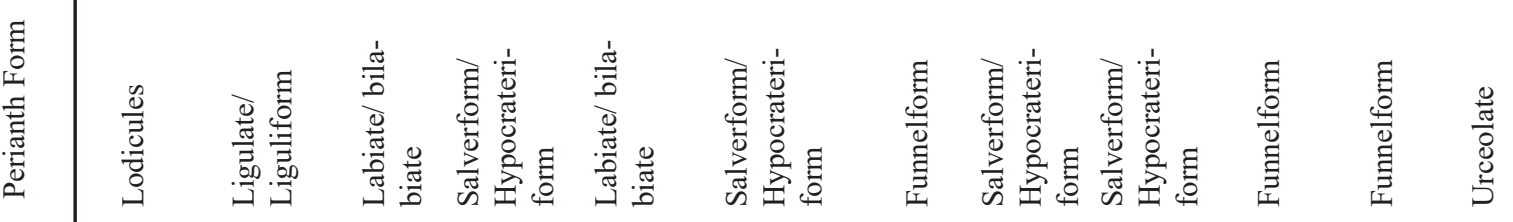

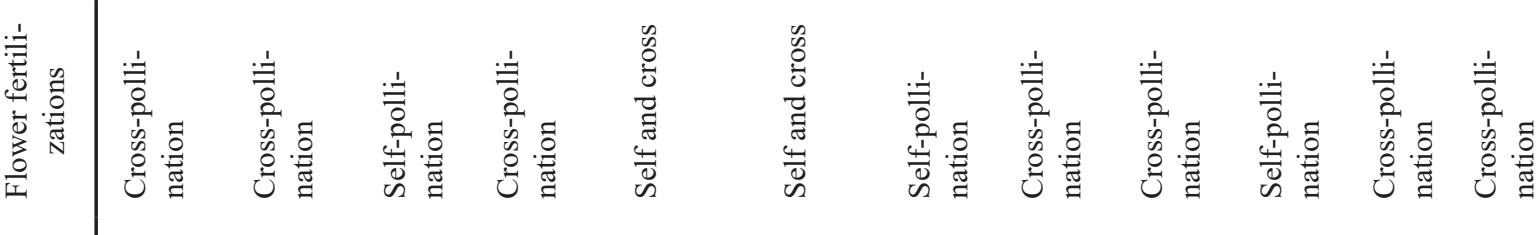

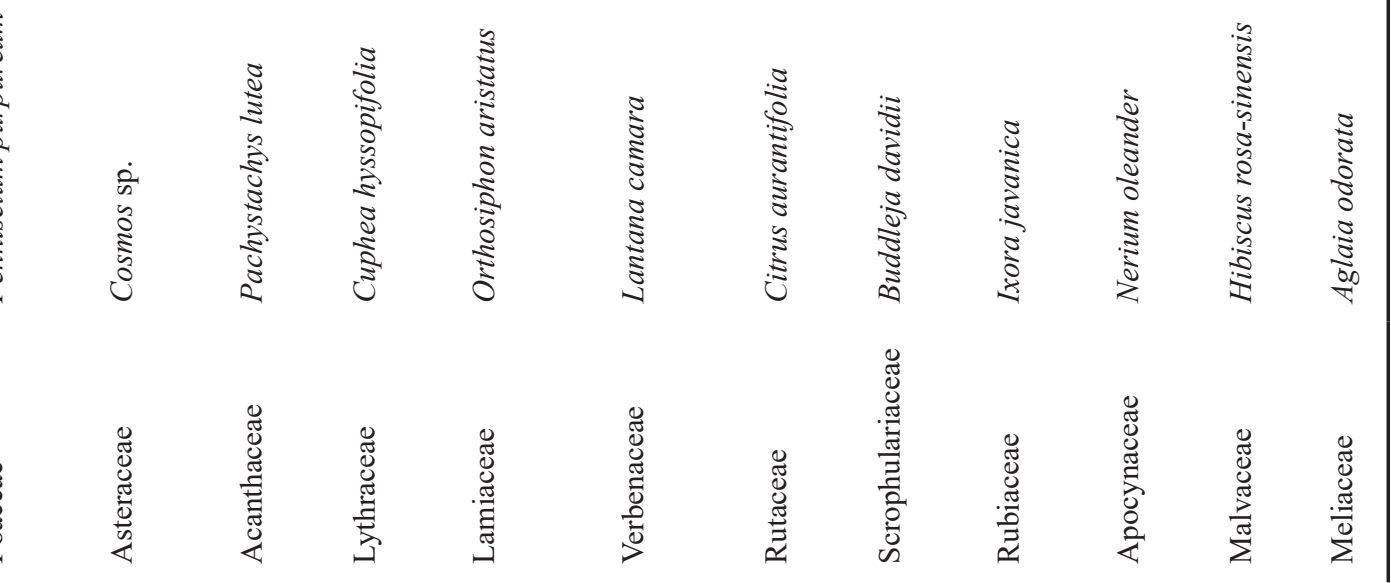

Jurnal Biodjati 5(2):223-235, November 2020 
Jurnal Biodjati 5(2):223-235, November 2020

\section{JURNAL BIDDJATI}

http://journal.uinsgd.ac.id/index.php/biodjati

Table 2. List of species and the relative abundance of pollinator insects at Pollination Gardens

\begin{tabular}{|c|c|c|c|}
\hline Ordo & Family & Species & Relative abundance (\%) \\
\hline \multirow[t]{23}{*}{ Lepidoptera } & \multirow[t]{8}{*}{ Nymphalidae } & Doleschallia bisaltide & 0.29 \\
\hline & & Euploea sp. & 0.58 \\
\hline & & Hipolimnas bolina & 1.45 \\
\hline & & Junonia atlites & 28.90 \\
\hline & & Junonia erigone & 11.27 \\
\hline & & Junonia hedonia & 6.07 \\
\hline & & Neptis hylas & 2.89 \\
\hline & & Ypthima sp. & 8.38 \\
\hline & \multirow[t]{4}{*}{ Papilioninae } & Graphium agamemnon & 0.58 \\
\hline & & Papilio demolion & 0.58 \\
\hline & & Papilio demoleius & 0.29 \\
\hline & & Papilio polytes & 1.16 \\
\hline & \multirow[t]{5}{*}{ Pieridae } & Appias lyncida & 0.58 \\
\hline & & Appias nero & 8.67 \\
\hline & & Appias olferna & 2.02 \\
\hline & & Eurema sp. & 15.32 \\
\hline & & Leptosia nina & 5.20 \\
\hline & \multirow[t]{3}{*}{ Lycaenidae } & Lycaenidae 1 & 1.16 \\
\hline & & Lycaenidae 2 & 2.60 \\
\hline & & Lycaenidae 3 & 0.58 \\
\hline & \multirow[t]{3}{*}{-} & Sp. $1^{*}$ & 0.58 \\
\hline & & Sp. $2^{*}$ & 0.58 \\
\hline & & Sp. $3 *$ & 0.29 \\
\hline \multirow[t]{9}{*}{ Hymenoptera } & \multirow[t]{5}{*}{ Apidae } & Amegilla sp. & 36.29 \\
\hline & & Apis cerana & 4.84 \\
\hline & & Tetragonula sp. & 2.42 \\
\hline & & Thyreus sp. & 11.29 \\
\hline & & Trigona sp. & 6.45 \\
\hline & Megachilidae & Megachile sp. & 1.61 \\
\hline & Scoliidae & Campsomeris sp. & 11.29 \\
\hline & \multirow[t]{2}{*}{ Vespidae } & Phimenes sp. & 10.48 \\
\hline & & Polistes sp. & 15.32 \\
\hline
\end{tabular}

Butterflies that belong to Nymphalidae family were most commonly found in the pollination garden. They have polyphagic properties that allow them to have more than one type of food/ host (Priyono \& Abdullah, 2013). Also, the environmental conditions of the pollination garden, which were slightly open with good airflow supported the species of Junonia atlites (28.90\%), Junonia erigone (11.27\%) and Junonia hedonia (6.07\%) to have a relatively high abundance (Indriani et al., 2010) reported that Junonia atlites in Tanjung Puting National Park are often found in open bushland. This type of butterflies likely live in open habitat with high ambient temperatures. 


\section{JURNAL BIDDJATI}

http://journal.uinsgd.ac.id/index.php/biodjati

The highest relative abundance of Hymenoptera was Amegilla sp. (36.29\%) with blue-banded body details showing that this species likes to fly in an open area exposed to sunlight under the canopy (Kato et al., 2008). In addition, this species also has long glossa (a tongue-like structure in the labium of an insect's mount parts), so it tends to visit flowers with deep tubes and brightly colored flowers such as blue-white. In general, (Miller et al., 2011) described that bees (bee-pollinated) generally attracted to blue and yellow flowers. Besides that, flowers that have nectar guide can increase pollinators visit flowers because it helps bees finding the nectar (Hansen et al., 2012; Leonard et al., 2013). Other relative abundances were Polistes sp. (15.32\%), Campsomeris sp. (11.29\%), and Phimenes sp. (10.48\%), which live solitary and predatory. These species often visit flowers to look for prey, namely caterpillars and small bees. Nevertheless, the presence of Polistes sp., Phimenes sp., and Campsomeris sp. who visit these flowers are also useful in the pollination process (Parikesit et al., 2018; Prakash Gautam \& Kumar, 2018).

The biodiversity values of Lepidoptera was higher than Hymenoptera (Table 3). The index of species diversity ( $\left.\mathrm{H}^{\prime}\right)$ of Lepidoptera in the pollination garden was classified as moderate (2.34), while Hymenoptera was classified as low (1.86). It was directly proportional to the value of the two species of pollinators. Meanwhile, the index of species evenness of pollinator species showed low value $(\mathrm{E}<0.1)$. It shows that in pollination garden could be found individual species domination, while other species were part of subdominant or not dominant.

Table 3. Diversity parameters of pollinators

\begin{tabular}{ccc}
\hline Parameter & Lepidoptera & Hymenoptera \\
\hline Richness index $(\mathrm{R})$ & 3.76 (moderate) & 1.66 (low) \\
Diversity index $\left(\mathrm{H}^{\prime}\right)$ & 2.34 (moderate) & 1.86 (low) \\
Evenness index $(\mathrm{E})$ & 0.10 (low) & 0.21 (low) \\
\hline
\end{tabular}

The best time to observe pollinating insects in the pollination garden was at 08.3009.30 GMT+7 (Figure 2). It was in line with (Priyono \& Abdullah, 2013), who stated that butterflies would be active and fly well when the sunlight intensity increases as butterflies need heat to help them fly. Insects which were mostly found during the best observe times were Eurema sp., Junonia atlites, Junonia erigone, Appias nero, Ypthima sp., Amegilla sp., and Phimenes sp.

\section{Potential Pollination Garden}

The pollination garden candidate area at Bogor Botanic Gardens has considerable potential to bring pollinating insects, such as butterflies and bees. It will undoubtedly become one of the new alternative gatherings and educational places at the Bogor Botanic Gardens which is full of information and knowledge for visitors. Based on the observation, the five most-visited plants by pollinators were Cuphea hyssoppifolia, Lantana camara, Orthosiphon aristatus, Cosmos sp., and Pachystachys lutea (Figure 3). Cuphea hyssoppifolia has nectaries at the base of long corolla tube so that advantages for Hymenoptera and Lepidoptera to reach it with their more extended proboscis (Safriya \& Karunaratne, 2011). 


\section{JURNAL BIDDJATI}

http://journal.uinsgd.ac.id/index.php/biodjati

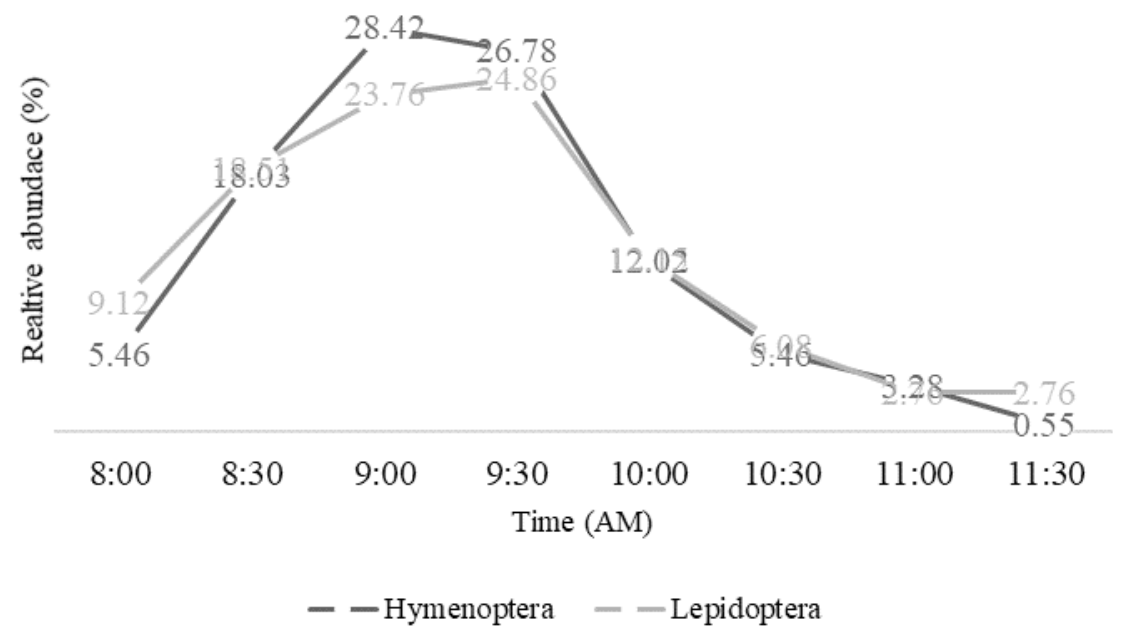

Figure 2. Insects visited the flowers

Flowers were attractive to pollinators

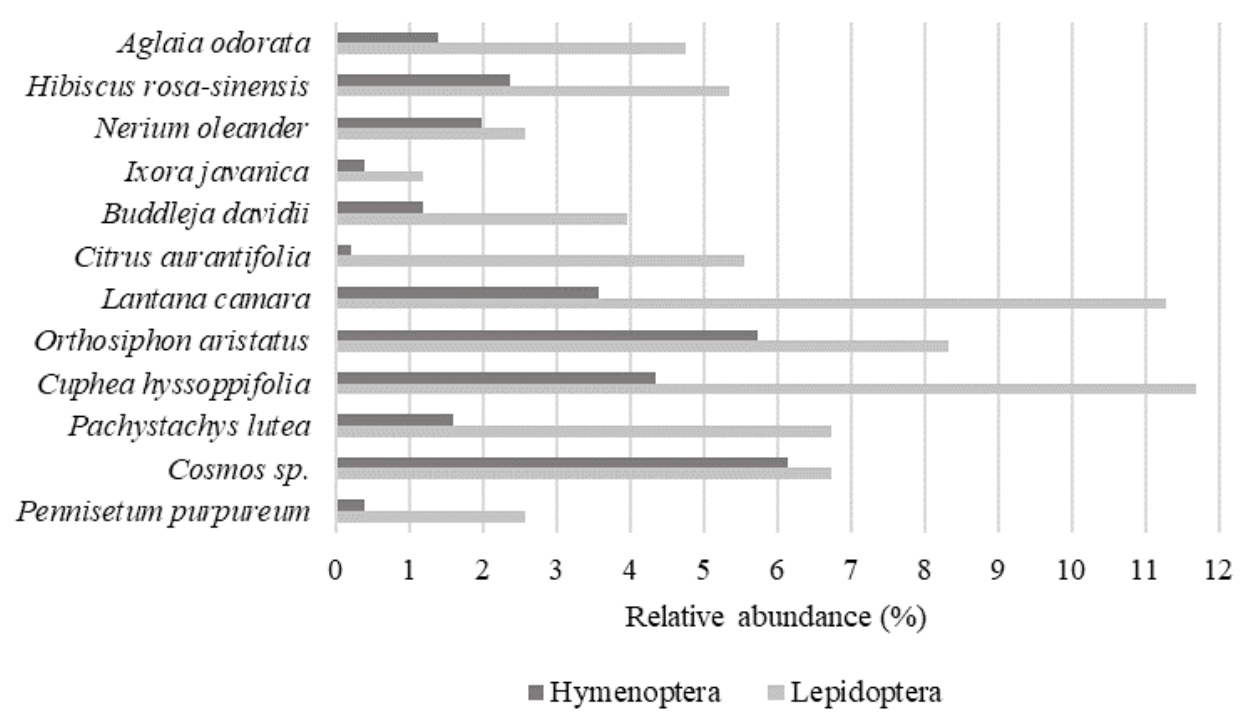

Figure 3. Plant visited by pollinators

Most of the selected plant has a diverse flower characteristic to attract Hymenoptera and Lepidoptera. Cuphea hyssoppifolia was the most commonly visited by insects because the flowers emerge in the terminal and have a lot of numbers and perianth with the form of Hypocrateriform, which is a purple tube and small in size. It allows Hymenoptera and Lepidoptera to take nectar at the bottom of the Peniwidiyanti et al. ovary of the flower with the proboscis (Safriya \& Karunaratne, 2011).

The second most commonly visited species was Lantana camara, which has an umbel type inflorescence in terminals. Thus allowed insects to visit at the same time. Moreover, the corolla color, which changes from yellow in the opening, then changes to orange and gradually changes to reddish-orange, acts as the 


\section{JURNAL BIDDJATI}

http://journal.uinsgd.ac.id/index.php/biodjati

indicator of pollen maturity and nectar content (Barrows, 1976; Priyanka \& Joshi, 2013). Therefore, Lantana camara is visually appealing for pollinators.

Orthosiphon aristatus was one of the most visited species by bees because of the variety of flower colors, including purple, intermediate (purple-white), and white (Febjislami et al., 2019). It is also has a raceme inflorescence and blooms from the bottom to the top. The flowering period was quite long, which was around 2-3 weeks. Therefore, it allowed the pollinator to visit the inflorescence in a longer period multiple times.

However, some plant species were not preferable to pollinators due to some characters. For instance, Ixora javanica and Hibiscus rosa-sinensis had fewer visitors, Lepidoptera and Hymenoptera, because of the red flowers. Flowers with brightly colored characters such as red are generally more attractive to birds than bees (Hails \& Kavanagh, 2013). Bees learn rapidly the association of colour, rewards, and its costs (Chittka \& Wells, 2004), somehow the topic of bee vision and colour preference still has a long argument. Pennisetum purpureum was not a type of insect-pollinated plant, but the leaves were commonly used by butterflies to perch or to lay butter eggs. The pollination of Pennisetum purpureum is assisted by wind, and the spikelet color not flashy (colorful), making it less attractive to pollinating insects in the morning. Citrus aurantifolia and Aglaia odorata are also species of plants with a strong scent with an inconspicuous color and flower shape, so both species of plants are widely used by butterflies to perch and lay their eggs.

\section{Ornamental Plant for Landscape Design of Pollination Garden}

The principal component analysis was used to determine the plant species that can attract pollinating insects from the relatives of Lepidoptera and Hymenoptera. Based on the insect group found shows that the relatives of Lepidoptera are divided into three groups (Figure 4), namely the group that has the highest relative frequency and relative abundance consisting of just one species, namely Junonia atlites. The second group of butterflies is common and has a medium frequency of visits. This group of butterflies has similar plant species preferences: zygomorphic flower type, perianth flower in the form of labiate and umbel, white, yellow, and purple, and has a medium aroma. In contrast, the third group is the butterfly group that has a low relative abundance of species. Generally, these species come to visit the pollination garden only occasionally to sunbath and perch on plants. However, the presence of this third butterfly group can increase the diversity value of butterflies in the pollination garden, especially if the plant characters fit the group preferences. In addition, there is one species of butterfly that is an outlier, Neptis hylas, which has a living preference in the shaded area or under the canopy (Saikia, 2014). Thus, in compiling the pollination garden landscape design, the habitat and feed conditions should be adjusted to the preferences of the second and third groups so that the potential for butterflies that come is higher.

Furthermore, the analysis of the main components in the Hymenoptera is divided into two large groups and additional outliers of two species (Figure 5), namely the Amegilla sp. and Polistes sp. Both of these species have a big difference in habitat and food preferences. Amegilla sp. is a solitary honey bee that prefers areas that are not exposed to direct sunlight and flowers that provide lots of nectar and pollen, such as the type of Cuphea hyssopifolia, Cosmos sp., and Orthosiphon aristatus. While Polistes sp. is a predatory wasp that 


\section{JURNAL BIDDJATI}

http://journal.uinsgd.ac.id/index.php/biodjati

visited many species of plants, especially in the areas that are open and exposed to direct sunlight. The most visited plant by Polistes sp. was Cuphea hypssopifolia because this plant is commonly visited by Apis cerana, Amegilla sp. and Trigona sp., which is a prey of Polistes sp.. The first group consisted of three species of predators that have relatively high abundance in the pollination garden, namely Thyreus sp., Campsomeris sp. and Phimenes sp. These three species of predators may be one of the factors making other species of pollinators relatively low. A second group is a group of common pollinating bee species from Apidae family who prefer yellow, orange, pink, white to magenta flowers with a type of inflorescence of the form of a head and medium and light floral scent.

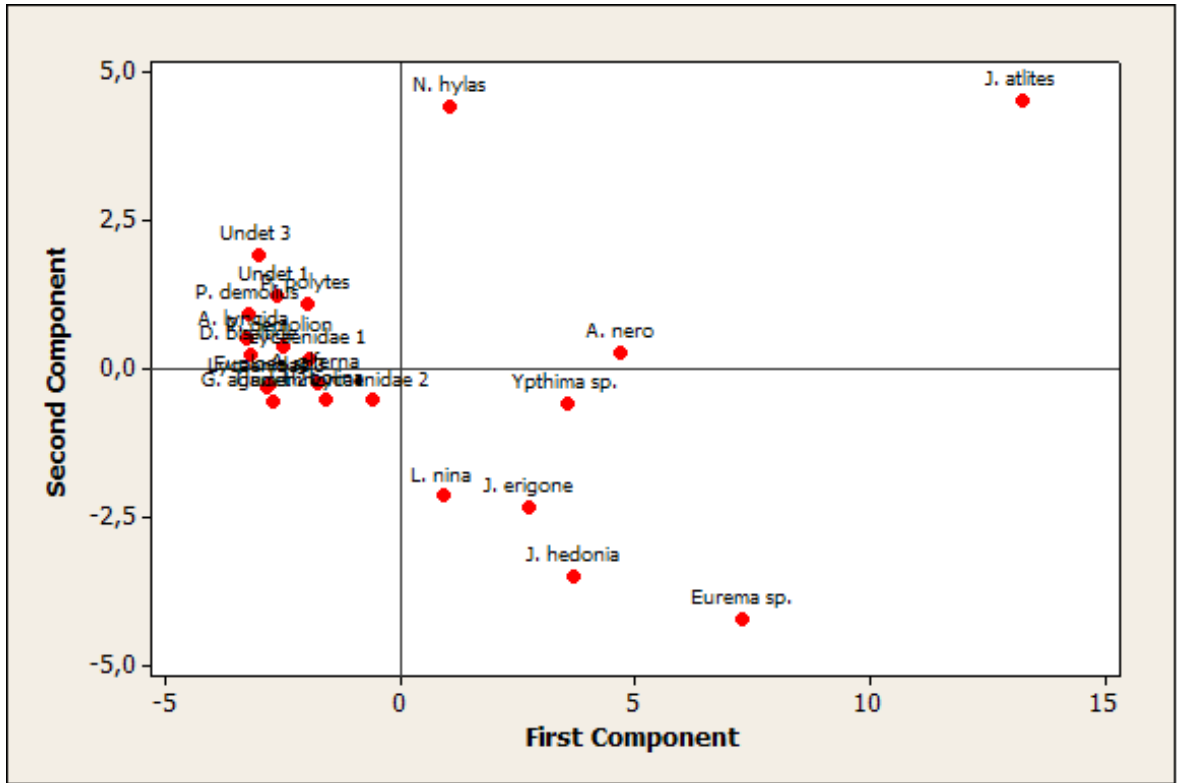

Figure 4. Principal Component Analysis of Lepidoptera

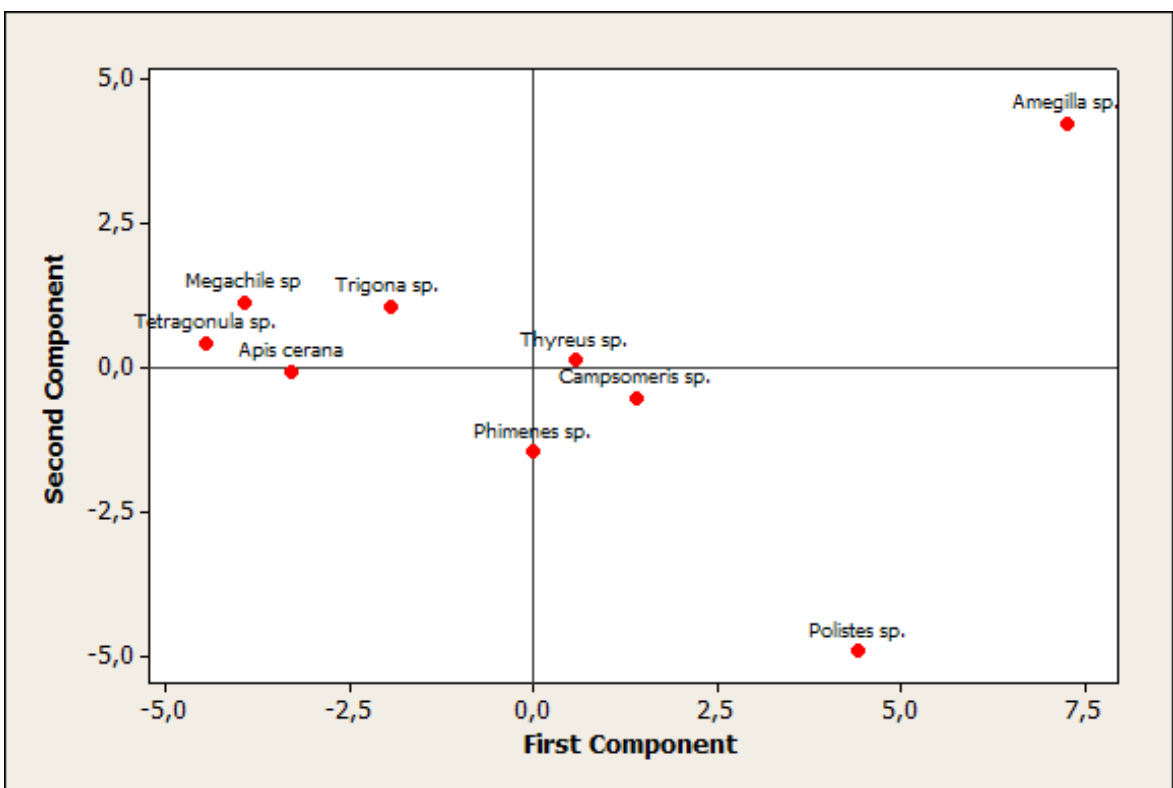

Figure 5. Principal Component Analysis of Hymenoptera 


\section{JURNAL BIDDJATI}

http://journal.uinsgd.ac.id/index.php/biodjati

The constituent plants which are suggested to attract Lepidoptera and Hymenoptera in the pollination garden are species that have white, yellow, or purple to magenta flowers with less scent. The preferable forms of the inflorescence are head, raceme, umbel, and the shape of the flower crown in the form of labiate and hypocrateriform. In addition, it is important to provide suitable plant species to feed the pollinators larvas, which is not only providing space for insects to breed but also providing a platform to lay eggs such as the Citrus aurantifolia and Aglaia odorata.

Pollinators from Lepidoptera (butterflies order) and Hymenoptera (bees order) preferred plants with particular flower characters in color, flower symmetry, inflorescent, and scent. Lepidoptera and Hymenoptera preferred blue-purple and bright-orange-yellow flowers or inflorescence. Lepidoptera preferred zygomorphic flowers in the form of labiate and umbel inflorescences. In contrast, Hymenoptera liked flowers that have a flower pad for them to perch as in the inflorescence of the head, shape, umbel. Both groups had a preference for light to medium scented flowers. The plant species that are highly recommended to be included in the garden design are Cuphea hyssopifolia, Lantana camara, and Orthosiphon aristatus, or any other local plants with similar flower characters.

\section{ACKNOWLEDGEMENTS}

Thank you to the Research Center for Plant Conservation and Botanic Gardens (Indonesian Institute of Sciences) LIPI for the support of research funding mechanisms through the 2018 In-House Research. Our deep gratitude to Mrs. Djunijanti Peggie and Mr. Sih Kahono from Research Center of Biology - LIPI for the opportunity to discuss and validate the insect species. A special thanks to Heri Destrianto, Akbar Alif Pribadi, Ningsih, and Alan Handru for assisting in the collection and identification of the insect, and the maintenance collection staff for the generous assistance in the field. We appreciate two anonymous reviewers who provided helpful comments to improve and clarify this manuscript.

\section{REFERENCES}

Ardhianto, D., FMIPA U., Sari, R. \& Djalil, A. (2009). 54732-ID-none.pdf. Buletin Kebun Raya Indonesia, 12(1), 19-27.

Barrows, E. M. (1976). Nectar Robbing and Pollination of Lantana camara (Verbenaceae) Author (s): Edward M. Barrows Published by The Association for Tropical Biology and Conservation Stable URL: http://www.jstor.org/stable/2989633. Association for Tropical Biology and Conservation, 8(2), 132135.

Budiadi, Musyafa, Hardiwinoto, S. \& Syahbudin, A. (2020). Changes in insect biodiversity on rehabilitation sites in the southern coastal areas of java island, Indonesia. Biodiversitas, 21(1), 1-7.

Chittka, L. \& Wells, H. (2004). Colour Vision in Bees. In Prete, F. R. Complex Worlds from Simpler Nervous Systems. Cambridge, Massachusetts \& London, England: A Bradford Book, The MIT Press.

Febjislami, S., Kurniawati, A. N. I., Melati, M. \& Wahyu, Y. (2019). Morphological Characters, Flowering and Seed Germination of the Indonesian Medicinal Plant Orthosiphon aristatus. Biodiversitas, 20(2), 328-337.

Hails, C. J. \& Kavanagh, M. (2013). Bring Back the Birds! Planning for Trees and Other Plants to Support Southeast Asian 


\section{JURNAL BIDDJATI}

http://journal.uinsgd.ac.id/index.php/biodjati

Wildlife in Urban Areas. Raffles Bulletin of Zoology, SUPPL. 29, 243-258.

Hansen, D. M., van der Niet, T. \& Johnson, S. D. (2012). Floral Signposts: Testing the Significance of Visual "Nectar Guides" for Pollinator Behaviour and Plant Fitness. Proceedings of the Royal Society B: Biological Sciences, 279(1729), 634-639.

Indriani, Y., Ginoga, L. \& Masy'ud, B. (2010). Keanekaragaman Jenis Kupu-Kupu di Beberapa Tipe Habitat di Pondok Ambung Taman Nasional Tanjung Puting Kalimantan Tengah. Media Konservasi, 15(1), 1-12.

Kahono, S. \& Mursidawati, S. (2010). Komunitas Serangga pada Bunga Rafflesia patma Blume (Rafflesiaceae) di Luar Habitat Aslinya Kebun Raya Bogor Kota Bogor Provinsi Jawa Barat Indonesia. Jurnal Biologi Indonesia, 6(3), 429-442.

Kato, M., Kosaka, Y., Kawakita, A., Okuyama, Y., Kobayashi, C., Phimminith, T. \& Thongphan, D. (2008). Plant-Pollinator Interactions in Tropical Monsoon Forests in Southeast Asia. American Journal of Botany, 95(11), 1375-1394.

Kunte, K. J. (1997). Seasonal Patterns in Butterfly Abundance and Species Diversity in Four Tropical habitats in northern Western Ghats. Journal of Biosciences, 22(5), 593-603.

Kwatrina, R., Santosa, Y., Bismark, M. \& Santosa, N. (2018). Ecological Impacts of Oil-palm Plantation on Butterfly and Bird Species Diversity. Jurnal Manajemen Hutan Tropika, 24(1), 23-31.

Leonard, A. S., Brent, J., Papaj, D. R. \& Dornhaus, A. (2013). Floral Nectar Guide Patterns Discourage Nectar Robbing by Bumble Bees. PLoS ONE, 8(2), 1-6.

Miller, R., Owens, S. J. \& Rørslett, B. (2011).
Plants and Colour: Flowers and pollination. Optics and Laser Technology, 43(2), 282-294.

Mitter, C., Davis, D. R. \& Cummings, M. P. (2017). Phylogeny and Evolution of Lepidoptera. Annual Review of Entomology, 62, 265-283.

Ollerton, J. (2017). Pollinator Diversity: Distribution, Ecological Function, and Conservation. Annual Review of Ecology, Evolution, and Systematics, 48, 353-376.

Parikesit, Paramita, A., Withaningsih, S. \& Kasmara, H. (2018). Ecosystem Services in Coffee (Coffea arabica L.) Production System in the District of West Bandung, West Java: The Community Structure and Diversity of "direct and Indirect" Pollinator Insects. IOP Conference Series: Earth and Environmental Science, 197(1), 1-13.

Peters, R. S., Krogmann, L., Mayer, C., Donath, A., Gunkel, S., Meusemann, K., Kozlov, A., Podsiadlowski, L., Petersen, M., Lanfear, R., Diez, P. A., Heraty, J., Kjer, K. M., Klopfstein, S., Meier, R., Polidori, C., Schmitt, T., Liu, S., Zhou, X. \& Niehuis, O. (2017). Evolutionary History of the Hymenoptera. Current Biology, 27(7), 1013-1018.

Prakash Gautam, P. \& Kumar, N. (2018). Pollinator Diversity and Relative Abundance of Insect Pollinators on Ridge Gourd (Luffa acutangula) Flowers in Bihar (India). Journal of Entomology and Zoology Studies, 6(2), 1177-1181.

Priyanka, N. \& Joshi, P. K. (2013). A Review of Lantana camara Studies in India. International Journal of Scientific and Research Publications, 3(10), 1-11.

Priyono, B. \& Abdullah, M. (2013). Keanekaragaman Jenis Kupu-Kupu di Taman Kehati Unnes. Biosaintifika, 5(2), 1-6. 


\section{JURNAL BIDDJATI}

http://journal.uinsgd.ac.id/index.php/biodjati

Safriya, M. \& Karunaratne, W. (2011). Cuphea hyssopifolia (Lythraceae): Floral Morphology and Associated Insects. Proceedings of the Peradeniya University Research Sessions, Sri Langka. 16, 147.

Saikia, Kakati, M. \& Saikia, P. (2014). Ecology of Butterflies in Tropical Scattered Forest of Manas Biosphere Reserve, Assam , India. Journal of Global Bioscience, 3(3), 660-680.

Soegiharto, S. \& Kartono, A. P. (2009). Karakteristik Tipe Pakan Kelelawar Pemakan Buah dan Nektar di Daerah Perkotaan: Studi kasus di Kebun Raya Bogor. Jurnal Biologi Indonesia, 6(1), 119-130.

Subahar, T. \& Yuliana, A. (2010). Butterfly Diversity as a Database for the Development Plan of Butterfly Garden at Bosscha Observatory, Lembang, West Java. Biodiversitas, Journal of Biological Diversity, 11(1), 24-28.

Tati-Subahar, S. S., Amasya, A. F. \& Choesin, D. N. (2007). Butterfly (Lepidoptera: Rhopalocera) Distribution Along an Altitudinal Gradient on Mount Tangkuban Parahu, West Java, Indonesia. Raffles Bulletin of Zoology, 55(1), 175-178.
Utami, N. \& Kahono, S. (1989). Penyerbukan pada Pinang Yaki (Areca vestiaria) di Kebun Raya Bogor. Berita Biologi, 3, 470-472.

Vanbergen, A. J., Espíndola, A. \& Aizen, M. A. (2018). Risks to Pollinators and Pollination from Invasive Alien Species. Nature Ecology and Evolution, 2(1), $16-25$.

Webber, C., Peterson, A., Kelly, D. \& Clemens, J. (2012). Native and Exotic Flower Visitors in the Christchurch Botanic Gardens and Their Contrasting Plant Preferences. New Zealand Natural Sciences, 37, 37-49.

Winfree, R., Bartomeus, I. \& Cariveau, D. P. (2011). Native Pollinators in Anthropogenic Habitats. Annual Review of Ecology, Evolution, and Systematics, 42, 1-22. 